\title{
Grazing and Food Size Selection of Zooplankton Community in Lake Biwa during BITEX '93
}

\author{
Jotaro URABE, Keiichi KaWABata, \\ Masami NAKANISHi and Kensuke SHIMIZU
}

\begin{abstract}
Community grazing rate of zooplankton larger than $98 \mu \mathrm{m}$ in body size were examined at the north and south basins of Lake Biwa in late summer, 1993. The lake seston labeled with ${ }^{14} \mathrm{C}$ was divided into different size fractions $(<2,2-8,8-20$ and $20-70$ $\mu \mathrm{m}$ ), and the grazing rate for each size fraction was determined under ambient food condition. During the study period, Eodiaptomus japonicus dominated, followed by Daphnia galeata at both sites. In all experiments, the grazing rate was higher for middle size fractions (2-8 and 8-20 $\mu \mathrm{m})$ than the smallest and largest size fractions, indicating that the zooplankton communities selectively remove seston in the size range of 2-20 $\mu \mathrm{m}$. Community ingestion rate estimated from the grazing rate and abundance of ambient seston revealed that seston in the middle size fractions was main food of zooplankton. When abundance of seston $<20 \mu \mathrm{m}$ was low relative to those $>20 \mu \mathrm{m}$, however, the largest size fraction contributed $57 \%$ of the ingested carbon, suggesting that the food source of zooplankton is not necessarily restricted to the small sestonic particles, even if feeding efficiency was low for large sestonic particles. Based on grazing rate, 6 to $10 \%$ of total seston was estimated to be removed by the zooplankton community within a day.
\end{abstract}

Key Words : zooplankton, grazing, seston, Lake Biwa, BITEX '93, size selectivity.

\section{Introduction}

In pelagic systems, grazing by zooplankton can be important loss process in populations of resource organisms including planktonic algae, bacteria and protozoans (LAMPERT, 1988; HESSEN et al., 1989 ; STERNER, 1989 ; MAZUMDER et al., 1990 ; CARRICK et al., 1991 ; GASOL and VAQUE, 1993 ; URABE, 1994 ; URABE et al., 1995). However, zooplankton do not ingest these potential food organisms at equal rate. Due to physiological and physical constraints in feeding apparatus and behavior, there is a size dependence to zooplankton feeding (BURNS, 1968; GLIWICZ; 1969; HeSSEN, 1985 ; VANDER PLOEG, 1990 ; DEMOTT, 1990). In addition, some zooplankton taxa such as calanoid copepods, actively discriminate among food items based on chemical characteristics (BUTLER et al., 1989 ; DEMOTT, 1990; VANDERPLOEG, 1990). It is thus easily expected that species of the resource organisms differ in the extent to which they suffer grazing. Other than grazing, zooplankton can also affect phytoplankton by modulating nutrient cycling (STERNER, 1989; URABE, 1993, 1995 ; URABE et al., 1995). To understand the details of zooplankton impact on resource organisms and material flows in a given lake, however, quantitative data on grazing rate and diet selection are essential.

In Lake Biwa, the largest lake in Japan, several studies have examined the grazing rate and feeding selectivity of zooplankton species. URABE et al. (1995) showed that grazing by zooplankton can be a major loss process of sestonic particles in the epilimnion at the north basin of L. Biwa in some seasons. NAKANISHI $e t$ al. (1992) also reached the same conclusion based on primary production rate and literature data on feeding rate of the zooplankton species. 
Using elaborate methods with ambient food particles labeled by ${ }^{14} \mathrm{C}$, Окамото (1984a) indicated that two dominant zooplankton species, Daphnia galeata* and Eodiaptomus japonicus, selectively ingest smaller phytoplankton in L. Biwa. Nagata (1985) and Nagata and Oкамото (1988) examined the feeding rate of these zooplankton species for bacteria. According to them, Daphnia can ingest bacteria as efficiently as algae smaller than $25 \mu \mathrm{m}$, but Eodiaptomus not. Apart from these experimental studies, KaWABATA (1987) examined gut contents of D. galeata and E. japonicus, and found that large individuals of these species can ingest large algae such as Closterium aciculare and Melosira solida. However, these studies have examined feeding performance of zooplankton at species or population levels. There are no quantitative data about grazing impact of zooplankton community on food organisms in different size categories in L. Biwa.

During the BITEX '93 (an international research program entitled "Biwako transport experiment": KUMAGAI et al., 1995), we had an opportunity to examine intensively the grazing rate of zooplankton at the north and south basins of L. Biwa. Here, as a part of BITEX '93, we report the grazing rate of zooplankton community for food particles in different size categories.

\section{Materials and methods}

Grazing experiments were conducted under semi-in-situ conditions on 26 August and 3 September 1993. Zooplankton were collected at $1 \mathrm{~m}$ depth at Station $\mathrm{S}$ ( $3 \mathrm{~m}$ deep) in the south basin and $5 \mathrm{~m}$ depth at Station $\mathrm{N}(50 \mathrm{~m})$ in the north basin of Lake Biwa. The sampling depth was decided based on the vertical profile of zooplankton abundance: the zooplankton was most abundant in $5 \mathrm{~m}$ layer at Station $\mathrm{N}$, while apparent peak was not found in the vertical profile at Station S (KaWABATA and URABE, 1995). Community grazing rate was estimated

\footnotetext{
*This species had been reported as $D$. longispina hyalina (Окамото, 1984a, b) or D. longispina (NAGATA, 1985; Nagata and Okamoto, 1988 ; KaWabata, $1987 ; 1989$ ), but was identified as $D$. galeata (J. HRBACEK, pars. comm.).
}

for zooplankton that were retained on $98 \mu \mathrm{m}$ mesh net.

\section{2-1. Sampling and enumeration}

Two days before the grazing experiment, lake seston used as labeled food was collected at each station using a modified 10-L Van Dorn sampler at 9:30-11:00 hours. On each station and date when the grazing experiment was made, zooplankton with lake water was collected as mentioned above. Immediately after the sampling, the zooplankton were placed into 20-L tanks with lake water, mixed gently, and then transferred to 20 (26 Aug.) or 24 (3 Sept.) 1.1-L polycarbonate bottles without any concentration. These live zooplankton in the polycarbonate bottles were transported to a laboratory near the shore of the lake and used for the grazing experiments.

Simultaneous with the live zooplankton sampling, additional four 10-L zooplankton samples were collected to estimate biomass and composition. Among them, two were concentrated using a plankton net with $40-\mu \mathrm{m}$ mesh $(>40 \mu \mathrm{m}$ fraction). The remaining samples were filtered once through a $98 \mu \mathrm{m}$ mesh net and then concentrated with the $40 \mu \mathrm{m}$ mesh net $(40-98 \mu \mathrm{m}$ fraction). These samples were fixed with acid Lugol's solution. All individuals in the samples were counted for developmental stages in copepods and for size classes in cladocerans. There were few rotifers during the study period. Dry weight of each zooplankton was estimated according to length - weight relationships shown in Table 1. The composition and biomass of zooplankton $>98 \mu \mathrm{m}$ was determined from the difference between the $>40 \mu \mathrm{m}$ and $40-98 \mu \mathrm{m}$ zooplankton fractions.

Water samples were also collected to determine abundance and size composition of seston. According to SiEBURTH et al. (1978), seston was divided into three size fractions, pico- $(<2 \mu \mathrm{m})$, nano- $(2-20 \mu \mathrm{m})$ and micro-fractions ( $>20 \mu \mathrm{m})$, using a $2 \mu \mathrm{m}$ Nuclepore membrane filter and a $20 \mu \mathrm{m}$ mesh net. Sestonic particles in each fraction were concentrated onto precombusted Whatman GF/F glass-fiber filters. These filters were enveloped with pieces of aluminum foil and stored at $-20{ }^{\circ} \mathrm{C}$. Sestonic carbon onto the 
Table 1. Dry weight (DW : $\mu \mathrm{g}$ ) of individual crustaceans used to estimate zooplankton biomass. The furcal ramus of $M$. dissimilis copepodid stages, and head of D. galeata and B. longirostris are not included in the length (L: $\mathrm{mm}$ ). In $E$. japonicus, individual body weight directly estimated are used.

\begin{tabular}{lcc}
\hline \multicolumn{1}{c}{ Species } & Specific weight & Reference \\
\hline $\begin{array}{c}\text { Eodiaptomus japonicus } \\
\text { naupliar stage } \\
\text { copepodid stage }\end{array}$ & $\mathrm{DW}=3.47 \times \mathrm{L}^{2.26}$ & MCCAULY (1984) \\
I & $0.82 \mu \mathrm{g} \cdot$ ind $^{-1}$ & KAWABATA and URABE \\
II & 1.35 & \\
III & 2.57 & \\
IV & 3.84 & \\
V male & 5.14 & \\
V female & 5.64 & \\
VI male & 5.88 & \\
VI female & 7.81 & McCAULY (1984) \\
Mesocyclops dissimilis* & & MCCAULY (1984) \\
naupliar stage & $\mathrm{DW}=7.83 \times \mathrm{L}^{2.55}$ & URABE and WATANABE (1990b) \\
copepodid stage & $\mathrm{DW}=3.56 \times \mathrm{L}^{2.26}$ & MCCAULY (1984) \\
Daphnia galeata & $\mathrm{DW}=9.85 \times \mathrm{L}^{2.71}$ & URABE and WATANABE (1990b) \\
Diaphanosoma brachyurum & $\mathrm{DW}=5.07 \times \mathrm{L}^{3.05}$ & \\
Bosmina longirostris & $\mathrm{DW}=32.2 \times \mathrm{L}^{2.60}$ &
\end{tabular}

glass-fiber filter was analyzed with a $\mathrm{CHN}$ analyzer (Yanaco, model MT-3).

\section{2-2. Grazing experiments}

Grazing rate of zooplankton community was examined for food particles in four size fractions $(<2,2-8,8-20$ and $20-70 \mu \mathrm{m})$. In the present study, grazing rate $(G)$ is defined as water volume (liter) cleared per unit time (day) by zooplankton assemblage in unit water volume (liter).

Two days before the grazing measurements, the lake water collected at each station was filtered by $70 \mu \mathrm{m}$ nylon mesh screen and seston in the filtrate was labeled in $500 \mathrm{ml}$ aliquots with 200-250 $\mu \mathrm{Ci} \mathrm{NaH}{ }^{14} \mathrm{CO}_{3}$ for $48 \mathrm{hr}$ at constant light condition by cool-white fluorescent bulbs. Grazing experiments were performed under dim light condition at $26^{\circ} \mathrm{C}$ which was almost the same to the water temperature where the zooplankton samples were collected $\left(25 \sim 27^{\circ} \mathrm{C}\right)$. To initiate the grazing experiments, the labeled seston was filtered through either Nuclepore filters ( 2 or $8 \mu \mathrm{m}$ ) or nylon screen mesh (20 or
$70 \mu \mathrm{m}$ ). Then, $30-55 \mathrm{ml}$ from one of these filtrates was added to the 1.1-L Polycarbonate bottles containing the zooplankton. Thus, the amount of labeled seston was less than $5 \%$ of total seston in the bottle. For each fraction, four (26 Aug.) or three bottles (3 Sept.) were used for feeding trial and remaining two bottles were used for 0 -time measurement (see below).

During the feeding trial, two 1-ml aliquots of feeding suspension was sampled and filtered onto $0.2 \mu \mathrm{m}$ Sartorius filters to determine the radioactivity of the food. Animals were allowed to feed for $15 \mathrm{~min}$ according to Окамото (1984a).

At the end of feeding trial, the contents of the bottle were filtered through $98 \mu \mathrm{m}$ nylon mesh disk (45 $\mathrm{mm}$ in diameter). Zooplankton retained on the mesh disk were rinsed with $0.001 \mathrm{~N} \mathrm{HCl}$ and then several times with distilled water. Immediately after rinsing, the mesh disk with zooplankton was placed in a scintillation vial without any fixation to prevent loss of isotope. Liquid scintillation fluor $(10 \mathrm{ml}$ 
of Aquasol-2) was added to each vial within $2 \mathrm{hr}$ after the feeding trial, and radioactivity was measured with a liquid scintillation counter. Quenching correction was made by the external standard method.

To correct for errors due to labeled food retained on the mesh disk but not ingested by zooplankton, the contents of bottles for 0-time measurement were filtered onto the mesh disk immediately after the labeled food was injected. The radioactivity at 0 -time was usually less then $10 \%$ of that at the end of feeding trial. Quenching by the nylon mesh disk was also checked by putting a known amount of radioisotope into the scintillation vials containing 10 $\mathrm{ml}$ of the fluor, but no significant difference was detected in counting efficiency between vials with and without the mesh disk.

The grazing rate on each size fraction was calculated according to equations by MAZUM . DER et al. (1990). The grazing rate on food smaller than i $\mu \mathrm{m}\left(G_{i}: \mathrm{d}^{-1}\right)$ was calculated as follows,

$$
G_{i}=\left(Z_{i}-Z_{i}^{*}\right) \times(24 \mathrm{hr} \times 60 \mathrm{~min}) /\left(F_{i} \times t\right)
$$

where, $Z_{i}$ and $Z_{i}^{*}$ are radioactivity on the mesh disk $\left(\mathrm{dpm} \cdot 1^{-1}\right)$ at $t$ and $0, F_{i}=$ radioactivity in food $\left(\mathrm{dpm} \cdot \mathrm{1}^{-1}\right)$; and $t=$ feeding time (min). Then the community grazing rate for a size fraction $\left(G_{i j}: i<j\right)$ was estimated by

$$
G_{i j}=\left(G_{j} \times F_{j}-G_{i} \times F_{i}\right) /\left(F_{j}-F_{i}\right)
$$

Ingestion rate for a size fraction $\left(I_{i j}: i<j\right)$ was calculated by

$$
I_{i j}=S_{i j} \times G_{i j}
$$

where $S_{i j}$ is seston abundance in size fraction $i-j$. Total ingestion rate $\left(T I: \mu \mathrm{g} \mathrm{C} \cdot 1^{-1} \cdot \mathrm{d}^{-1}\right)$ and total grazing rate $\left(T G: \mathrm{d}^{-1}\right)$ were estimated as follows,

$$
\begin{aligned}
& T I=\Sigma\left(S_{i j} \times G_{i j}\right) \\
& T G=\Sigma\left(S_{i j} \times G_{i j}\right) / \Sigma S_{i j}
\end{aligned}
$$

Significant differences between grazing rates on different size fractions were examined by one-way ANOVA and post hoc Fisher's PLSD comparison test with the aid of a computer program package (Stat View SE+Graphics: FELDMAN et al., 1988).

\section{Results}

On 26 August, composition of zooplankton $>98 \mu \mathrm{m}$ was similar between Stations $\mathrm{N}$ and $\mathrm{S}$, and more than $59 \%$ of the zooplankton biomass was composed of copepodid stages of Eodiaptomus japonicus (Table 2). Daphnia galeata was also abundant and shared about $25 \%$ of the biomass at both stations. On 3 September, although $40 \%$ of the biomass was composed of $E$. japonicus at both stations, the zooplankton composition differed between the

\begin{tabular}{|c|c|c|c|c|c|c|c|c|}
\hline \multirow{3}{*}{ Taxon } & \multicolumn{4}{|c|}{26 Aug. } & \multicolumn{4}{|c|}{3 Sept. } \\
\hline & \multicolumn{2}{|c|}{ Station N } & \multicolumn{2}{|c|}{ Station S } & \multicolumn{2}{|c|}{ Station N } & \multicolumn{2}{|c|}{ Station S } \\
\hline & B & $\%$ & $\mathrm{~B}$ & $\%$ & $\mathrm{~B}$ & $\%$ & $\mathrm{~B}$ & $\%$ \\
\hline \multicolumn{9}{|l|}{ Eodiaptomus japonicus } \\
\hline nauplii & 0.5 & 0.2 & 2.0 & 1.2 & 1.4 & 0.5 & 1.6 & 1.0 \\
\hline copepodids & 123.3 & 59.1 & 107.7 & 65.0 & 121.7 & 40.5 & 73.2 & 47.6 \\
\hline \multicolumn{9}{|l|}{ Mesocyclops dissimilis } \\
\hline nauplii & 8.5 & 4.1 & 1.2 & 0.7 & 6.9 & 2.3 & 0.9 & 0.6 \\
\hline copepodids & 10.9 & 5.2 & 9.5 & 5.7 & 22.7 & 7.6 & 42.9 & 27.9 \\
\hline Daphnia galeata & 54.7 & 26.2 & 39.8 & 24.0 & 132.5 & 44.1 & 12.6 & 8.2 \\
\hline Diaphanosoma brachyurum & 10.8 & 5.2 & 5.5 & 3.3 & 15.2 & 5.1 & 22.5 & 14.6 \\
\hline Total & 208.7 & & 165.7 & & 300.4 & & 153.7 & \\
\hline
\end{tabular}
stations. On this date, D. galeata increased and made up $44 \%$ of the zooplankton biomass at Station $N$, while density of this species was low

Table 2. Biomass (B: $\left.\mu \mathrm{g} \mathrm{DW} \cdot 1^{-1}\right)$ and its percentage composition (\%) of zooplankton. 
and Mesocyclops dissimilis made up 28\% of biomass at Station S. The zooplankton biomass was higher at Station $N$ than Station $S$ on both dates. Biomass of metazoan zooplankton $<98$ $\mu \mathrm{m}$ was less than $1 \%$ of the zooplankton $>98$ $\mu \mathrm{m}$ during the study period (KAWABATA and URABE, 1995).

Although seston abundance was similar between the dates and stations, large difference was found in its size composition (Table 3). On 26 August, the abundance of seston in the 2-20 $\mu \mathrm{m}$ fraction was higher than those in other fractions at Station N. At Station S, however, the middle fraction $(2-20 \mu \mathrm{m})$ was less abundant compared to other size fractions. On 3 September, $70 \%$ of seston was composed of the

Table 3. Abundance of seston $\left(\mu \mathrm{gC} \cdot 1^{-1}\right)$ in different size fractions.

\begin{tabular}{lccccc}
\hline & \multicolumn{2}{c}{26 Aug. } & & \multicolumn{2}{c}{3 Sep. } \\
\cline { 2 - 3 } \cline { 5 - 6 } Size fraction & Station N & Station S & & Station N & Station S \\
\hline$<2 \mu \mathrm{m}$ & 131 & 180 & & 97 & 179 \\
$2-20 \mu \mathrm{m}$ & 185 & 133 & & 86 & 273 \\
$>20 \mu \mathrm{m}$ & 150 & 180 & & 412 & 117 \\
total & 466 & 493 & & 595 & 569 \\
\hline
\end{tabular}

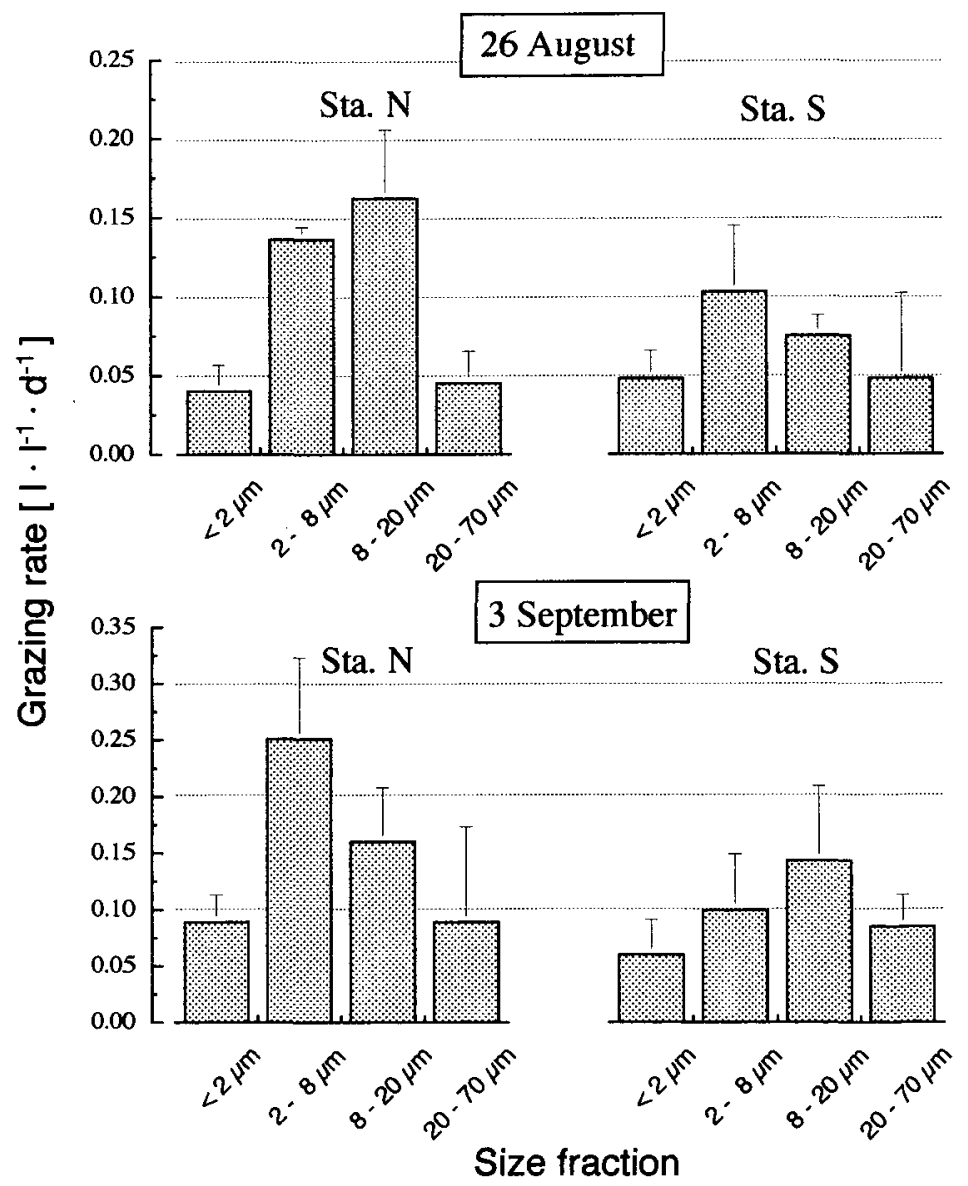

Fig. 1. Grazing rate of zooplankton community for food in different size fractions. Vertical bars are $3 \mathrm{SE}$ on the mean. 
largest fraction $(>20 \mu \mathrm{m})$ at Station $\mathrm{N}$, while the middle fraction contributed $50 \%$ of seston at Station S. Throughout the study period, dominant species of phytoplankton at Station $\mathrm{N}$ was Gomphosphaeria lacustris (Cyanophyceae), while at Station S, it was Melosira granulata (Bacillariophyceae) (Kumagal et al., 1955). Further information on abundance and composition of phytoplankton during the study period will be given in elsewhere (NAKANO et al., in prep).

The grazing rate differed significantly between food particles in different size fractions (Fig. 1). In all experiments, post hoc comparison test revealed that the grazing rate was significantly higher for middle fractions (2-8 $\mu \mathrm{m}$ and $8-20 \mu \mathrm{m})$ than the smallest size fractions (Table 4.). The grazing rate did not significantly differ between food particles in 2$8 \mu \mathrm{m}$ and $8-20 \mu \mathrm{m}$ except for 3 September at
Station $N$ where it was highest for 2-8 $\mu \mathrm{m}$ fraction. The grazing rate for the largest size fraction was significantly lower than those in either (Station S) or both (Station N) of the middle size fractions. On both dates, the grazing rate for food particles $<2 \mu \mathrm{m}$ was one half of that for $2-8 \mu \mathrm{m}$ at Station $\mathrm{S}$, while one third at Station N. This result implies that food size preference of the zooplankton community was less marked at Station S compared to Station N.

From the grazing rate and seston abundance in each size fraction, ingested carbon from each fraction was calculated (Fig. 2). Since we did not separate seston into $2-8$ and $8-20 \mu \mathrm{m}$ fractions, grazing rate for $2-20 \mu \mathrm{m}$ fraction was estimated by applying $G_{2}$ and $G_{20}$ to eq. 2 and then ingestion rate for that fraction was calculated using eq: 3 . The carbon ingested by the zooplankton community was mainly from the middle size fractions except for 3 September at

Table 4. Results of statistical analyses for grazing rates on different size fractions.

\begin{tabular}{|c|c|c|c|c|c|}
\hline \multirow[b]{2}{*}{ Date } & \multirow[b]{2}{*}{ Station } & \multicolumn{3}{|c|}{ ANOVA } & \multirow[b]{2}{*}{ Multiple comparison* } \\
\hline & & df & $F$ & $P$ & \\
\hline \multirow[t]{2}{*}{26 August } & $\mathrm{N}$ & 3,8 & 53 & 0.001 & $\leq 2,20-70, \quad 2-8,8-20 \mu \mathrm{m}$ \\
\hline & $\mathrm{S}$ & 3,8 & 4.5 & 0.038 & $<2,20-70, \quad 8-20, \quad 2-8 \mu \mathrm{m}$ \\
\hline \multirow[t]{2}{*}{3 September } & $N$ & 3,12 & 13.6 & 0.001 & $<2,20-70, \quad 8-20,2-8 \mu \mathrm{m}$ \\
\hline & $\mathrm{S}$ & 3,12 & 5.1 & 0.017 & $\leq 2,20-70,2-8, \quad 8-20 \mu \mathrm{m}$ \\
\hline
\end{tabular}

*Significant difference at $5 \%$ level is denoted by different underlines

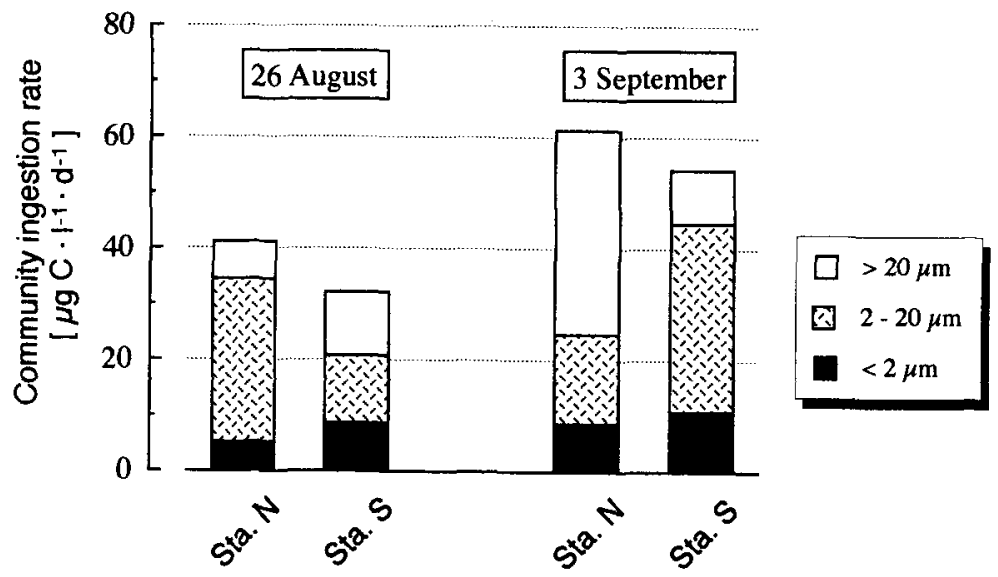

Fig. 2. Community ingestion rate of zooplankton and contribution of each food size fraction to the ingestion rate. 
Station $\mathrm{N}$ where $57 \%$ of the ingested carbon was from the largest size fraction. The contribution of the smallest size fraction to the ingested carbon was lowest in all dates and stations.

Total ingestion and total grazing rates are shown in Table 5. A two-fold difference was found in the total ingestion rate among the experiments. The total ingestion rate was lowest on 26 August at Station S and highest on 3 September at Station N. Weight-specific ingestion rate (normalized by zooplankton biomass) also varied with the highest value on 3 September at Station $\mathrm{S}$. The total grazing rate was in the range from 0.065 to 0.103 liter $\cdot 1^{-1}$. $\mathrm{d}^{-1}$, implying that the zooplankton community removed 6.5 to $10.3 \%$ of seston within a day. The weight-specific grazing rate was relatively stable among the experiment and in the range from 0.4 to 0.6 liter $\cdot \mathrm{mg} \mathrm{DW}^{-1} \cdot \mathrm{d}^{-1}$.

\section{Discussion}

Окамото (1984a) indicated that E. Japonicus and $D$. galeata individuals ingest preferentially smaller algae in the warm water season. However, since he used algae smaller than $10 \mu \mathrm{m}$ as the smallest food size category, vulnerability of picoplankton to the zooplankton grazing has been unclear. In the present study, the grazing rate for the smallest fraction $(<2 \mu \mathrm{m})$ was always lower than that for the middle fractions (nanoplankton: $2-8 \mu \mathrm{m}$ and $8-20 \mu \mathrm{m}$ ). The result implies that picoplankton are less vulnerable to the zooplankton grazing compared to nanoplankton both at the north and south basins. The lower grazing rate for picoplan- kton was probably due to predominance of $E$. japonicus, because calanoid copepods in general do not ingest preferentially picoplankton (see review in STERNER, 1989 ; VANDERPLOEG, 1990). NAGATa and Окамото (1988) demonstrated that E. japonicus cannot ingest bacteria efficiently.

A number of studies have examined bacterial ingestion of daphnid species (TezUKA, 1971; Nagata and OKamoto, 1988; Hessen et al. 1989, Urabe and Watanabe 1990a, 1991, and literatures therein). Among them, NAGATA and Окамото (1988) suggested that, contrasting with E. japonicus, Daphnia galeata in L. Biwa is an efficient bacterial feeder. The present study, however, does not coincide with their conclusion. It should be noted that picoplankton include organisms larger than bacteria, such as solitary cyanobacteria. Thus, if $D$. galeata is an efficient bacterial feeder, we can expect an increase in the grazing rate for picoplankton relative to that for nanoplankton with increasing the proportion of this species. At the north basin, $D$. galeata increased and made up about one half of the zooplankton biomass on 3 September. Nonetheless, the grazing ratio of picoto nanoplankton on 3 September at the north basin was 0.35 , being similar to or smaller than those in other date and sites $(0.29-0.60)$. The results suggest that $D$. galeata is not necessarily more efficient at bacterial feeding than other zooplankton species in L. Biwa. From the feeding response to changes in bacterial and algal densities, URABE and WATANABE (1991) indicated that $D$. galeata does not rely on bacteria as

Table 5. Total and weight specific ingestion and grazing rates.

\begin{tabular}{cccccc}
\hline & \multicolumn{2}{c}{26 Aug. } & & \multicolumn{2}{c}{3 Sept. } \\
\cline { 2 - 3 } \cline { 5 - 6 } & St. N & St. S & & St. N & St. S \\
\hline $\begin{array}{c}\text { Total ingestion rate } \\
\left(\mu g^{\prime} \cdot 1^{-1} \cdot \mathrm{d}^{-1}\right)\end{array}$ & 41.2 & 32.1 & & 61.3 & 54.2 \\
$\begin{array}{c}\text { Specific ingestion rate } \\
\left(\text { ugC } \cdot \mathrm{mgDW}^{-1} \cdot \mathrm{d}^{-1}\right)\end{array}$ & 197.5 & 193.6 & & 204.1 & 352.5 \\
$\begin{array}{c}\text { Total grazing rate } \\
\left(1 \cdot \mathrm{I}^{-1} \cdot \mathrm{d}^{-1}\right)\end{array}$ & 0.088 & 0.065 & & 0.103 & 0.095 \\
$\begin{array}{c}\text { Specific grazing rate } \\
\left(1 \cdot \mathrm{mgDW}^{-1} \cdot \mathrm{d}^{-1}\right)\end{array}$ & 0.424 & 0.393 & & 0.343 & 0.620 \\
\hline
\end{tabular}


diet. Using labeled natural seston, MAZUMDER et al. (1990) demonstrated that the grazing rate in Daphnia-dominated community for sestonic particles $<3 \mu \mathrm{m}$ was far lower than that for $3-$ $8 \mu \mathrm{m}$ particles. On the other hand, Hessen $e t$ al. (1989) showed that $D$. longispina ingested bacteria as efficiently as algae in a dystrophic humic lake. Feeding ability and efficiency of Daphnia to picoplankton may differ not only between species but also clones and locatities with different nutritional conditions.

Higher grazing rate for a particular size fraction seems to suggest that the zooplankton ingest mainly food particles in that size category. However, such an image is incorrect. On 3 September at Station N when seston $>20 \mu \mathrm{m}$ was much abundant relative to seston $<20 \mu \mathrm{m}$ (Table 3), the largest size fraction (microplankton) contributed $57 \%$ of carbon ingested by the zooplankton (Fig. 2). Окамото (1984b) also indicated that about $50 \%$ of carbon ingested by $E$. japonicus and D. galeata was from seston larger than $25 \mu \mathrm{m}$ when large algal species dominated phytoplankton biomass. KAWABATA (1987) found a large number of algal cells $>30 \mu \mathrm{m}$, such as Closterium and Melosira, in the gut of E. japonicus and D. galeata when these algae were abundant in L. Biwa. Unfortunately, we do not have information on dominant phytoplankton species in the largest size fraction on 3 September at Station N. However, the results obtained here and previous studies suggest that the high ingestion rate for microplankton is not unusual in L. Biwa especially when large algae dominate phytoplankton biomass. This implies that the zooplankton grazing on the microplankton can not be negligible in material flows of this lake.

It should be noted, however, that the high ingestion rate for the largest fraction on 3 September at Station $\mathrm{N}$ simply results from a decrease in the amount of pico- and nanoplankton and increase in the microplankton available, but not due to changes in food size preference by the zooplankton assemblage. A food item with lower grazing rate implies less preferable food because of nutrient inadequacy or difficulty in detection, capture, handling or swal- lowing. Thus, material transfer efficiency from microplankton to zooplankton is expected to be low compared to that from nanoplankton even when zooplankton ingest microplankton more abundantly than nanoplankton.

In the present study, all individuals larger than $98 \mu \mathrm{m}$ in body size were treated as suspension feeders, although late stages of Mesocyclops dissimilis prey on zooplankton (KAWABATA, 1991). However, this species feeds also on phytoplankton (KAWABATA personal observation) and was limited in the density during the study period. Thus, although we included $M$. dissimilis in estimating the weight-specific grazing rate, such a treatment would not bring about serious error in our conclusion.

The weight-specific total ingestion rate estimated here, $198-356 \mu \mathrm{gC} \cdot \mathrm{mg} \mathrm{DW}^{-1} \cdot \mathrm{d}^{-1}$, is within the range of previous studies. On the basis of individual feeding rate, Окамото (1984b) calculated daily carbon rations of $D$. galeata and E. japonicus, being $16-77 \%$ of body carbon depending on body size in summer. Assuming 0.44 carbon: dry weight ratio (KAWABATA and URABE, unpubl.), these values correspond to the weight-specific ingestion rate of 70$339 \mu \mathrm{gC} \cdot \mathrm{mg} \mathrm{DW} \mathrm{DW}^{-1} \cdot \mathrm{d}^{-1}$. URABE et al. (1995) estimated particle elimination rate of the zooplankton community in L. Biwa, being $290 \mu \mathrm{g}$ $\mathrm{C} \cdot \mathrm{mg} \mathrm{DW}^{-1} \cdot \mathrm{d}^{-1}$ in average from June to November. Considering the difference in methodology, food condition and zooplankton composition among the studies, the total ingestion rate estimated here seems to coincide well with the previous results.

The community grazing rate of the zooplankton on total seston was less than $11 \%$ in all experiments. One may suspect that this grazing rate is too low to affect the seston abundance. However, since primary production is vertically limited to the shallow euphotic layer, but the zooplankton are not, the amount of carbon ingested by the zooplankton per unit area may be comparable to areal primary production rate even when grazing rate per unit volume is low. In other words, the magnitude of grazing impact on phytoplankton community depends not only on the community grazing rate but also primary 
production rate. Indeed, URABE et al. (1995). revealed that, on an areal basis, the amount of sestonic carbon ingested or removed by the zooplankton community is comparable to primary production rate in some seasons in the north basin of L. Biwa. Furthermore, even slight difference in food selectivity causes large changes in species composition of resource community (STERnER, 1989). Thus, the higher grazing rate for nanoplankton relative to picoand microplankton may play an important role in determining phytoplankton composition in $\mathrm{L}$. Biwa. Compared to the north basin, the south basin is eutrophic and more productive. Thus, although the community grazing rate was similar between the two basin, the grazing impact of zooplankton on phytoplankton community would be less conspicious in the south basin.

In the present study, the grazing experiments were conducted in limited season and site. The grazing impact on algal and bacterial populations is expected to change according to various factors including abundance and composition of zooplankton. In the south basin of L. Biwa, rotifers are usually abundant (MATSUBARA, 1993), although few rotifer individuals were found in the present study. To clarify the detailes of grazing impact on algal and bacterial populations in L. Biwa, therefore, further studies are needed on the feeding performance of zooplankton in different seasons and sites.

\section{Acknowledgments}

We are grateful to Michio Kumagal for his organization of BITEX '93. Without his effort and cooperation, we could not perform this study. We also wish to express our gratitude to Setsuo OKUDA who arranged use of a radioisotope laboratory, and to Masaru NISHIMURA and Toshiharu SuglHara, Toyobo Co., LTD, who provide us their lab space and facilities. Thanks are also due to Takaaki UEDA, Toshihiro MiyajIMA, Shin-ichi NAKano, Tatsuki SEKIno and Tadashi KolTabashi for their help in field and lab works, to crews of R/V Hakkengo for assistance on shipboard, and to Toshi NAGATA for his valuable discussion and assistance in lab works. Comments by Bob STERNER and anonymous reviewers improved the manuscript.

\section{摘要 \\ BITEX '93 期間中における琵琶湖動物プランク トン群集のグレージングと餌サイズ選択性}

1993 年 8 月から 9 月にかけて行われた Bitex '93の一環として,琵琶湖南湖及び北湖における動 物プランクトン群集のグレージング速度と餌サイ ズ選択性を調べた。摄慨実験にあたっては，採集

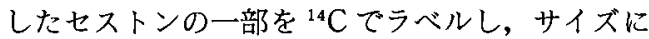
より 4 分画 $(<2,2 \sim 8,8 \sim 20$ 及び $20 \sim 70 \mu \mathrm{m})$ し た後，各サイズ分画に対するグレージング速度を 現場と同じ䬣環境下で測定した。実験時には Eodiaptomus japonicus と Daphnia galeata が動 物プランクトンとして卓越していた。

摂餌実験の結果，南湖・北湖ともに動物プラン クトン群集は 2〜20 $\mu \mathrm{m}$ のセストンを選択的に食 べ, $2 \mu \mathrm{m}$ 以下及び $20 \mu \mathrm{m}$ 以上のセストンに対す る提食圧は相対的に低いことが明らかとなった。 ただし，摄食量として見た場合，動物プランクト ンの餌は主に 2〜20 $\mu \mathrm{m}$ のセストンに限られると いうわけではなく，20 $\mu \mathrm{m}$ 以上のセストンに比心゙ て $20 \mu \mathrm{m}$ 以下のセストンが相対的に少ない場合 には, 動物プランクトンは $20 \mu \mathrm{m}$ 以上の大型藻類 を量的に多く摄食することが示唆された。実験期 間中における動物プランクトン群集の 1 日あたり 摄食量は，琵琶湖セストン量の 6〜 10\% になると 見積もられた。

\section{References}

Burns, C. (1968): The relationship between body size of filter-feeding cladocera and the maximum size of particle ingested. Limnol. Oceanogr., $13: 675-678$.

Butler, N. M., C. A. Suttle and W. E. Neill (1989) : Discrimination by freshwater zooplankton between single algal cells differing in nutritional status. Oecologia (Berlin), $78: 368-372$.

Carrick, H. J., G. L. Fahnenstiel, E. F. Stoermer and R. G. WeTzEL (1991): The importance of zooplankton-protozoan trophic couplings in Lake Michigan. Limnol. Oceanogr., 36 : 13351345.

Defaye, D. and K. Kawabata (1993): Mesocyclops dissimilis n. sp. from Lake Biwa, Japan (Copepoda, Cyclopoida). Hydrobiologia, 257: 121126.

DeMotT, W. R. (1990) : Retention efficiency, perce- 
ptual bias, and active choice as mechanisms of food selection by suspension-feeding zooplankton. p. 569-594. In R. N. Hughes, (Ed.), Behavioral mechanisms of food selection. Springer, New York, USA.

Feldman, D. S., JR., J. GaGnon, R. Hofman and J. SimPSON (1988): Stat View + Graphics: the solution for data analysis and presentation graphics. Abacus Concepts, California, USA.

GASOL, J. M. and D. VAQUE (1993) : Lack of coupling between heterotrophic nanoflagellates and bacteria: a general phenomenon across aquatic systems? Limnol. Oceanogr., $38: 657-665$.

Guıwicz, Z. M. (1969): Studies on the feeding of pelagic zooplankton in lakes with varying trophy. Ekol. Pol. (Ser. A), $17: 663-707$.

Hessen, D. O. (1985) : Filtering structures and particle size selection in coexisting cladocera. Oecologia (Berlin), $66: 368-372$.

Hessen, D. O., T. Andersen and A. Lyche (1989): Differential grazing and resource utilization of zooplankton in a humic lake. Arch. Hydrobiol., $114: 321-347$.

KaWABATA, K. (1987) : Ecology of large phytoplankters in Lake Biwa : population dynamics and food relations with zooplankters. Bull. Plankton Soc. Jpn., 34: 165-172.

KawabatA, K. (1989): Seasonal changes in abundance and vertical distribution of Mesocyclops thermocyclopoides, Cyclops vicinus and Daphnia longispina in Lake Biwa. Jpn. J. Limnol., $50: 9$ 13.

KaWABATA, K. (1991) : Ontogenetic changes in copepod behaviour: an ambush cyclopoid predator and a calanoid prey. J. Plankton Res., $13: 27-$ 34.

KaWABATA, K. and J. URABE (1995): Spatial and temporal changes in zooplankton biomass. In Biwako Transport Experiment Baseline Data Overviews. Lake Biwa Research Institute, Shiga Prefecture, Japan.

Kumagai, M., S. Nakano, J. Imberger, A. Hirayama, A. WAKE, Y. ITAKURA, S. ENdoh, Y. OKumura, R. TSUdA, Y. TANaKa, T. Kimoto, H. Hashitani, Y. Seike, M. Okumura, K. Fujinaga, T. Sato, M. NAKanishi, T. Sekino, T. Nagata, J. Frenette, W. Vincent, L. Legendre, J. Urabe and $K$. KAWABATA (1995): Reports of the symposia at the 59th conference of the Japanese Society of Limnology. 2. Some results of Biwako Transport Experiment (BITEX '93) : biogeochemical changes due to the horizontal transport between the north and the south basins of Lake Biwa. Jpn. J. Limnol. 56 : 151-156.
LAMPERT, W. (1988): The relationship between zooplankton biomass and grazing: a review. Limnólogia 45 : 11-20.

McCauly, E. (1984): The estimation of the abundance and biomass of zooplankton in samples. p. 228-265. In J. A. Downing and F. R. RIGLER (Eds.), A manual on methods for the assessment of secondary productivity in freshwaters. Black. well, New York, USA.

Matsubara, T. (1993): Rotifer community structure in the south basin of Lake Biwa. Hydrobiologia, 271 : 1-10.

Mazumder, A., D. J. McQueen, W. D. Taylor, D. R. S. LEAN (1990) : Micro- and mesozooplankton grazing on natural pico- and nanoplankton in contrasting plankton communities produced by planktivore manipulation and fertilization. Arch. Hydrobiol., 118 : 257-282.

Nagata, T. (1985): Filter mesh-size of Daphnia longispina and its filtering rates on natural bacteria. Mem. Fac. Sci. Kyoto Univ. (Ser Biol.), $10: 109-114$.

Nagata. T. and K. OKaмoto. (1988) : Filtering rates on natural bacteria by Daphnia longispina and Eodiaptomus japonicus in Lake Biwa. J. Plankton Res., $10: 835-850$.

Nakanishi, M., Y. Tezuka, T. Narita, O. Mitamura, K. Kawabata and S. Nakano (1992): Phytoplankton primary production and its fate in pelagic area of Lake Biwa. Ergeb. Limnol., 35 : $47-64$.

Okamoтo, K. (1984a): Size-selective feeding of Daphnia longispina hyalina and Eodiaptomus japonicus on a natural phytoplankton assemblage with the fractionizing method. Mem. Fac. Sci. Kyoto Univ. (Ser Biol.), $9: 23-40$.

Okамото, K. (1984b) : Diurnal changing patterns of the in situ size-selective feeding activities of Daphnia longispina hyalina and Eodiaptomus japonicus in a pelagic area of Lake Biwa. Mem. Fac. Sci. Kyoto Univ. (Ser Biol.), 9 : 107-132.

Sieburth, J. M., V. Smetacek and J. LenZ (1978): Pelagic ecosystem structure: heterotrophic compartments of the plankton and their relationship to plankton size fractions. Limnol. Oceanogr., $23: 1256-1263$.

Sterner, R. W. (1989): The role of grazers in phytoplankton succession. p. 197-170. In U. SoMmer (Ed.), Plankton ecology : succession in plankion communities. Springer, New York, USA.

TezukA, Y. (1971): Feeding of Daphnia on planktonic bacteria. Jpn. J. Ecol., $21: 127-134$.

URABE, J. (1993): N and P cycling coupled by 
grazer's activities: food quality and nutrient release by zooplankton. Ecology, 78: 23372350.

URABE, J. (1994) : Effect of a zooplankton community on seston elimination in a restored pond in Japan. Restoration Ecol., $2: 61-70$.

URABE, J. (1995): Direct and indirect effects of zooplankton on seston stoichiometry. Ecoscience, 2 :

URABE, J. and Y. WATANABE (1990a) : Difference in the bacterial utilization ability of four cladoceran plankton (Crustacea : Cladocera). Nat. Hist. Res., $1: 85-92$.

URABE, J. and Y. WATANABE (1990b) : Influence of food density on respiration rate of two crustacean plankters, Daphnia galeata and Bosmina longirostris. Oecologia, (Berlin), $82: 362-368$.

URABE, J. and Y. WATANABE (1991) : Effect of food conditions on the bacterial feeding of Daphnia galeata. Hydrobiologia, 225 : 121-128.

URABE, J., M. NAKANISHI and K. KaWABata (1995) : Contribution of metazoan plankton to the cycling of $\mathrm{N}$ and $\mathrm{P}$ in Lake Biwa. Limnol. Oceanogr., $40: 232-241$.
VANDERPLoEG, H. A. (1990) : Feeding mechanisms and particle selection in suspension-feeding zooplankton. p. 183-212. In R. S. WotToN (Ed.), The biology of particles in aquatic systems. CRC press, Boston, USA.

（著者：占部城太郎 ${ }^{*}$, 清水研助, 東京都立大学生物 学教室, ₹192-03 東京都八王子市南大沢 1-1；川幡佳 一, 金沢大学教育学部生物, 产920-11 石川県金沢市角 間町 : 中西正已, 京都大学生態学研究センター, テ $520-$ 01 滋賀県大津市下坂本 4-1-23; *現住所, 京都大学生 態学研究センター: Jotaro URABE*, Kensuke SHIMIZU, Department of Biology, Tokyo Metropolitan University, Minami-ohsawa 1-1, Hachioji, Tokyo 192-03 ; Keiichi Kawabata, Department of Biology, Faculty of Education, Kanazawa University, Kakuma-machi, Kanazawa, Ishikawa 920-11 ; Masami NAKANISHI, Center for Ecological Research, Kyoto University, Shimosakamoto, Otsu, Shiga 520-01: *Present address, Center for Ecological research, Kyoto University)

Received : 5 July 1995

Accepted : 15 November 1995 